International Research Journal of Engineering, IT \& Scientific Research
Available online at https://sloap.org/journals/index.php/irjeis/
Vol. 4 No. 4, July 2018, pages: 17 29
ISSN: 2454-2261
https://sloap.org/journals/index.php/irjeis/article/view/255

\title{
Renewable Energy Sources on the Change of Energy Matrix in Manabí Province
}

\author{
Jorge Lider Macias Ramos ${ }^{\text {a }}$ \\ Antonio Vázquez Pérez ${ }^{b}$ \\ María Rodríguez Gámez ${ }^{\mathrm{c}}$ \\ Raúl Vinicio Hidalgo Zambrano ${ }^{\mathrm{d}}$
}

Article history:

Received: 14 February 2018

Revised: 10 June 2018

Approved: 27 June 2018

Published: 3 July 2018

\section{Keywords:}

Efficiency;

Microgrids;

Quality of Life;

Renewable Energy;

Environmental Impact;

Distributed Generation;

Distributed Generation;

\begin{abstract}
The exploitation, distribution, and consumption of energy have caused the greatest environmental pollution on the planet and accelerated climate change; even though it has been the promoter of the social, economic development of many generations. Contemporary man can continue to increase his social development, but looking for alternatives to energy development. The work shows a model of energy development that will guarantee the sustainability of social development in the areas of the province of Manabí where energy arrives with low quality and in other places does not exist. The objective of the work is to propose the diversification of the energy matrix from the gradual and progressive introduction of technologies based on the use of renewable resources that it has was distributed in the territory of the province. This result will allow the use of indigenous renewable resources, reduce environmental pollution, and improve the quality of life of populations based on the principle of energy sustainability.
\end{abstract}

2454-2261 ${ }^{\odot}$ Copyright 2018. The Author. This is an open-access article under the CC BY-SA license (https://creativecommons.org/licenses/by-sa/4.0/) All rights reserved.

\section{Author correspondence:}

Jorge Lider Macias Ramos,

MsC. Civil Engineering, Electrical Engineering. Faculty of Science, Mathematics, Physics and Chemistry,

Universidad Técnica de Manabí, Portoviejo, Manabí, Ecuador

Email address:jlmacias@utm.edu.ec

\section{Introduction}

Science and technology are social processes in several important ways. Reassessing the social not as a scenario but as a decisive element is to start walking in a correct direction, the social help to understand science in context,

a MsC. Civil Engineering, Civil engineering career, Faculty of Science, Mathematics, Physics and Chemistry. Universidad Técnica de Manabí, Ecuador

b MsC. Degree in Law, Civil engineering career, Faculty of Science, Mathematics, Physics and Chemistry. Universidad Técnica de Manabí, Ecuador

${ }^{c}$ Ph.D., Engineering in electricity, Faculty of Science, Mathematics, Physics and Chemistry. Universidad Técnica de Manabí, Ecuador

${ }^{\mathrm{d}}$ Architect Faculty of Science, Mathematics, Physics and Chemistry. Universidad Técnica de Manabí, Ecuador 
which here points to the framework of economic, political and cultural circumstances that give meaning and direction to a determined scientific practice [1].

On the other hand, scientific and technological knowledge is one of the main riches of contemporary societies and an essential element to promote economic and social development. Science, technology, and innovation have become necessary tools for the transformation of productive structures, the rational exploitation of natural resources, health care, nutrition, education and other social requirements [2], [3].

In the global framework of the traditional philosophy of energy provision, privatization, the lack of transparency of information and the absence of regulation go hand in hand to form a scenario characterized by a centralized planning of anarchic tendency of the generation and distribution of electricity, where the interests of the juicy economic gains of the energy business remain as primary axes of development, above the principles of social efficiency of energies; understood as the capacity of these, to ensure the achievement of the goals of economic and social progress, without having to depend on the supply of resources from abroad, even if they are considered, in such a way as to ensure the harmonious functioning of the economy and society, in full relationship and exchange respectful of the environment.

The current energy disposition policy has its modern expression as an instrument of power, which employs as threads of submission, energy and technological dependence and as a social catalyst Neoliberalism, to subdue the economies of poor and developing countries, to the political interests of the powers.

The model achieved so far is conducive to the development of trade and economic progress of an increasing consumer society, its results are conducive to exclusion, inequality, environmental impacts, energy, technology and political dependence, manifesting itself as an instrument of hegemonic power which has its clearest expression in the overflow of cyclical energy crises and armed conflicts as the only possible solution to these contradictions.

These relationships correspond to an obsolete and obsolete social model, imposing the need to operate substantial changes in the way of thinking, planning and making energy, based on a new philosophy that takes as a standard a paradigm of energy sustainability and at the same time guarantees the sustainability of the system, taking advantage of the natural resources with the application of technologies within the reach of the territories and where the local authorities are responsible for the energy destination from the stage of study, investment, implementation, exploitation, maintenance, and consumption, is that reliable way to achieve the social efficiency of the energies.

The company is in constant interaction with the energy and the elements of nature, it is its main client and its regulator provided that an adequate level of consumption is reached that dynamizes these processes.

Therefore, the implementation of a new energy policy that reaches the dimension of the social right of energy, aimed at socialization, transparency of processes and legal and technical regulation, aligned with the interests of the nation's economic development; but enrolled in the principles of the social validity of energy, in correspondence to the satisfaction of the needs of society.

An analysis is made on the relationship between energy and renewable sources, highlighting the importance of the latter for the articulation of a sustainable energy matrix. It highlights the role that science can play in the process of changes and transformations that are required to implement, exposing the need to develop a healthy and respectful life for all forms of life on the planet, above the satisfaction of needs energetics of society.

The scope of the project is shown in terms of diversifying the energy matrix through the use of renewable sources and addressing some of the experiences obtained in the province of Manabí during the study of renewable energy sources and the implementation of the proposed model. As new results are shown the maps related to the study of solar potential, wind and what has been studied of hydraulics and biomass in the province of Manabí.

The objective of the work is to demonstrate the social feasibility of carrying out the diversification of the energy matrix of the province of Manabi, through the gradual and progressive use of renewable energy sources, printing a bias of sustainable renewability and where the appropriate use of resources and the use of technologies within the reach of the country's possibilities, at the same time guaranteeing the sustainability of the system.

\section{Research Methods}

An assessment of the renewable potentials in the province of Manabí is made from studies carried out by different authors and institutions and incorporating the biomass and hydraulic potentials that are being studied today; in addition to using the free access cartography of the Instituto Geográfio Militar (IGM) of Ecuador, information on the solar and wind potencales published by NASA [4].

The Geographic Information System (GIS) was used, which is defined by the National Center for Geographical Information and Analyzes (NGCIA) as a tool or hardware system (HW), software (SW) and designed procedures, to 
facilitate obtaining, management, manipulation, analysis, modeling and output of spatially referenced data, to solve complex problems of planning and management "[2]. It is a method or technique for the processing of geographic information, which allows to effectively combine basic information to obtain derived information. To do this, we have both sources of information and a set of tools that will facilitate this task; all framed within a project that will have been defined by a group of people and controlled by the technicians responsible for its implementation and development "[5].

\section{Results and Analysis}

A principios del siglo XX el consumo anual de energía por persona estaba calculado en 610 kilogramos equivalentes de petróleo y ya en el año 2000 los países europeos presentaban un per cápita de 2000 kilogramos equivalentes; es que el diseño tecnológico de la matriz energética tradicional, responde preferencialmente a garantizar una determinada cantidad de energía, sin tener en cuenta el verdadero derroche que se produce del total contenida en las fuentes primarias convencionales, para citar un ejemplo: en un país industrializado se pierde aproximadamente el $70 \%$ de energía total de las fuentes primarias: hasta un $30 \%$ se desperdicia en la transformación de las fuentes, el $10 \%$ en el traslado y el $30 \%$ en su uso final, quedando sólo un $30 \%$ de energía útil [6], según se demuestra gráficamente en la figura 1.

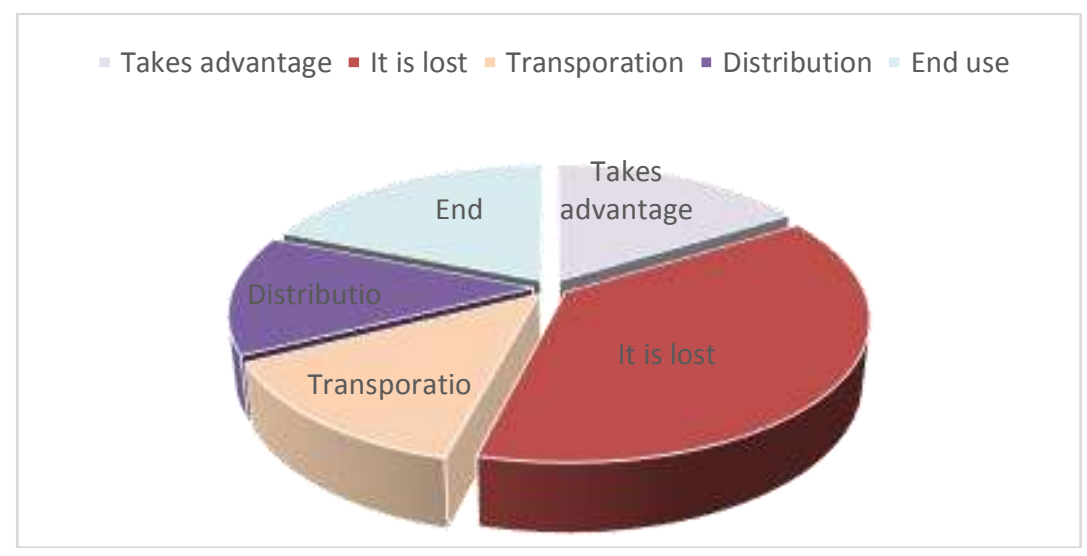

Figure 1. The average coefficient of use of primary energy from fossil fuels in industrialized countries Source: [10]

The current scenario becomes more critical if one considers that, in the forecasts for global energy demand, it is estimated that in only 20 years it could double. It is argued that the use of fossil fuels will continue to prevail in the global energy matrix, calculating that it would provide $81 \%$ of primary energy demand in 2030 . This is corroborated in the calculations offered by the International Energy Association, which projects that the demand for oil will grow almost $40 \%$ between 2006 and 2030 .

The unthinking and irrational policy of energy provision is motivating, that $\mathrm{CO} 2$ emissions are increasing even more and the world continues to heat up rapidly, even above what was reported in 2007 by the Intergovernmental Panel on Climate Change (IPCC) ). Arctic sea ice has decreased by approximately $10 \%$ in the last decade and the Arctic could become free of ice by 2030, the acidity of the oceans continues to rise, creating dead zones and reducing its capacity to absorb $\mathrm{CO} 2$ [10].

Already by the second half of the 20th century, the effects of the overexploitation of fossil fuels and the environmental consequences of this policy began to manifest, between 1950 and 2002, the consumption of fossil fuels had quintupled and $\mathrm{CO} 2$ emissions had increased. increased by $400 \%$, bringing with it increased pollution, climate change, deforestation, soil degradation, contamination of aquifer reserves and other dramatic consequences [11].

Just to offer a reliable sample of these impacts, we can point out that in the pre-industrial era there was an atmospheric concentration of $\mathrm{CO} 2$ of 270 parts per million, nowadays it exceeds 380 parts per million [12]. In an official document issued by ECLAC, it is recognized that despite the fact that the Latin American and Caribbean area, they do not find themselves as major emitters of greenhouse gases, compared with other countries and regions,

Ramos, J. L. M., Pérez, A. V., Gámez, M. R., \& Zambrano, R. V. H. (2018). Renewable energy sources on the change of energy matrix in Manabí province. International Research Journal of Engineering, IT \& Scientific Research, 4(4), 17-29. https://doi.org/10.21744/irjeis.v4n4.255 
the CO2 emissions of the year 2004 exceeded by $75 \%$ those registered in 1980, which meant a sustained growth of around $2.4 \%$ per year. This tendency seems difficult to modify if there are no active policies for this purpose [2].

The results of the application of the traditional energy policy are worrisome, taking into account that the electricity generation industry is based on the burning of fossil fuels, going hand in hand with the demand, the solutions to the problems of the increase in power generation, continue to find answers by introducing traditional energy systems, with a discrete penetration of renewable systems, causing that far from reducing environmental impacts, they continue to accumulate.

At a global level, the demand is often heard, in an effort to all those who are involved in guaranteeing the energy supply, so that it is carried out with the minimum environmental cost. It is necessary that researchers, companies, and institutions work in close collaboration to give a response, in the key of "sustainable development", to the change that society demands [13]. Some personalities pose; that the real problem is the lack of awareness of the energy issue that societies have, that is why it is increasingly necessary, dissemination and training plans to change the mentality regarding the use of energy [14].

It is evident the need to operate substantial changes in the way of thinking, planning and making energy, based on a new philosophy that takes as a standard, a paradigm of energy sustainability and that at the same time guarantees the sustainability of the system, taking advantage of natural resources own with the application of technologies within the reach of the territories and where local authorities are responsible for the energy destination, from the stage of study, investment, implementation, exploitation, maintenance and consumption, being that, a reliable way to achieve social efficiency of the energies, because not only of energy, man lives. The evaluation of the characteristics for the absorption of artisanal bricks was carried out based on the maximum absorption value with a percentage greater than $25 \%$ of the INEN regulations.

\subsection{GIS, as a tool in decision making}

A GIS is defined by the National Center for Geographical Information and Analyzes (NGCIA) as: "A hardware system (HW), software (SW) and procedures designed to facilitate the collection, management, manipulation, analysis, modeling and output of spatially referenced data, to solve complex problems of planning and management "[2].

It can be defined as "that method or technique of processing geographic information, which allows effectively combining basic information to obtain derived information. To do this, we have both sources of information and a set of tools that will facilitate this task; all framed within a project that will have been defined by a group of people and controlled by the technicians responsible for its implementation and development "[11]. Figure 2 shows the functional scheme of the GIS and its implementation to reduce losses and improve the energy efficiency designed for the work project.

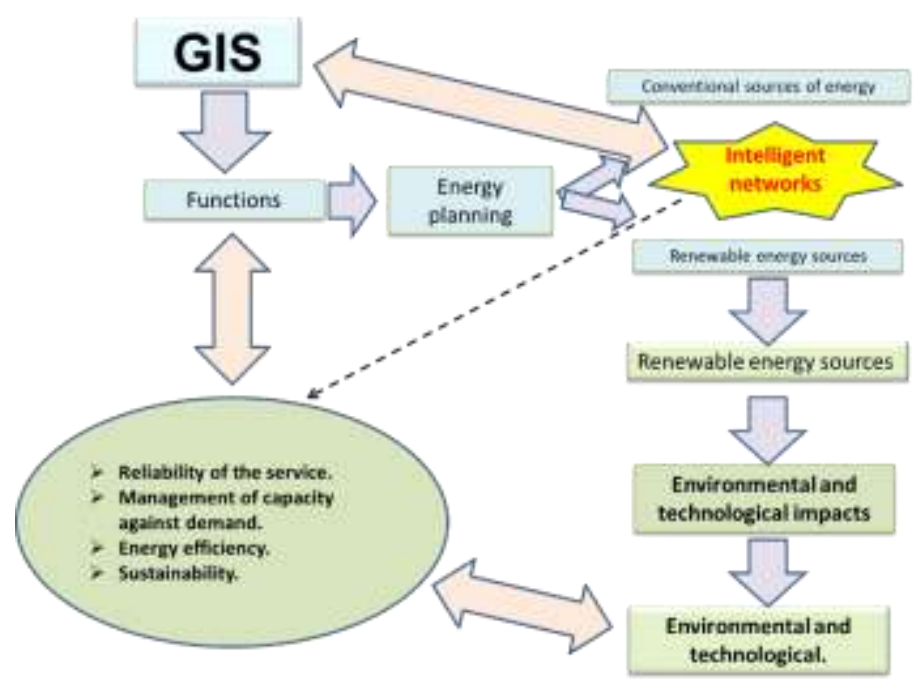

Figure 2. SIG designed to reduce losses and improve efficiency 
A GIS is a tool capable of combining graphics information (spatial representation of geographical objects) and alphanumeric (attributes of geographic objects), to obtain a resulting information about space. The GIS possess multiple tools that allow analyzing the territory, these are grouped in the following functions [12]:

a) Input functions: allow the capture of information, both the import of other digital sources and the digitalization of analog sources.

b) Output functions/graphics and cartographic representation of the information: it refers to the activities that serve to show the user, the information incorporated in the database and the results of the operations performed on them.

c) Spatial information management functions: with which the portions that interest at any time is extracted from the database, enables the organization of information.

d) Analytical functions: facilitates the processing of data integrated into the GIS, so that information that was unknown at the time of departure can be obtained.

e) Many are the arguments that allow defending the GIS, as a powerful and valuable tool in any type of territorial analysis, among them the following should be highlighted:

f) The incorporation of information with different levels of detail, making the changes between the scales and the projections more flexible.

g) They facilitate the processing of data, both qualitative and quantitative, providing a valuable capacity for calculations.

h) They are able to manage relevant volumes of information.

i) They allow integrating graphics and alphanumeric information.

j) They provide the user and/or programmer with standardized computer tools that make it possible to implement multiple development applications.

k) Application of GIS for pre-feasibility studies and loss reduction for the implementation of renewable technologies and energy efficiency

Energy has been an element that has allowed the growth and evolution of the territories, hence the importance of continuing to pay special attention to its management, defining the primary objective of this activity, to be able to choose the most appropriate solutions in the achievement of regions. balanced and energy-efficient [5].

The urgency to introduce renewable sources in the country's energy matrix does not respond to a spontaneous phenomenon derived from the volitional capacity of society; Since the first years of the second half of the last century, work has been done on the introduction of different technologies at a local level, mainly in isolated areas with adequate natural and landscape potential, designing social projects that have influenced the population, economic growth and all the activities inherent in the development of society.

This process, characterized by a strong renewed will, requires a rigorous territorial energy planning, which as a distinctive feature is integrated by a succession of planning and management figures, where they can be expressed in maps and plans at different scales, the different types and Information volumes, being the GIS, an ideal tool for solving problems in terms of studying the territory globally.

Its characteristic and differentiating elements allow us to reflect the conditions of the environmental, social, cultural and geographical environment (topography, hydrology, etc.). Allowing the transparency of these processes through the publication of useful data to managers, professionals, technicians and the population in general, offering information in real time on the energy development of the territory and the perspectives of development in the short, medium and long terms [5].

There are some experiences on the application of GIS in the energy management of other scenarios, among which we can point out the following: realization of economic technical feasibility studies of the energy development variables that can be applied to a territory, to improve the quality of life of the people who live next to the generation centers; analysis of the technical parameters in the application of geographic information systems, to the regional integration of renewable energies in the decentralized production of electricity [15]. These and other experiences constitute a starting point, in terms of structuring the studies of energy feasibility and economic feasibility in the planning of rural electrification.

The results presented above offer information supported by a study carried out over three decades, which shows the number of rural residents worldwide who have access to the electricity network, being able to verify that the figure has practically tripled, going from 610 million in 1970 to 1,400 million in 1990 [13]. Despite this, the total number of people without access to electricity has not declined significantly due to population growth, so that the world population without access to electricity remains at around 2,000 million people [14], although some authors

Ramos, J. L. M., Pérez, A. V., Gámez, M. R., \& Zambrano, R. V. H. (2018). Renewable energy sources on the change of energy matrix in Manabi province. International Research Journal of Engineering, IT \& Scientific Research, 4(4), 17-29. https://doi.org/10.21744/irjeis.v4n4.255 
consider this figure higher, close to 2.500 million people [16]. The majority of this population is located in developing countries, where it is estimated that there are 300 to 400 million households without electricity.

The versatility of the GIS has allowed the cartographic representation of natural resources, there are experiences in the field of solar resource evaluation, among others, the experiences obtained in Brazil using SWERA data [17], where they are presented the solar radiation maps, generated from satellite images, according to a model developed by the National Renewable Laboratory (NREL) of the United States [18].

The GIS is able to make feasible the complex process of study and knowledge in real time, of the various variables and parameters that must be valued by the decision makers, during the decision making the process for energy planning, from the use of the renewable energy.

\subsection{Scope of the project}

The distributed nature of the renewable sources and the diversity of the energy services that they are able to offer to indicate that a necessary turn in the philosophy of energy planning has was operated towards a decentralized scheme, where the territory plays a leading role in satisfying its needs, at the expense of its own resources with sustainable solutions.

A certain region to become sustainable must have the greatest autonomy possible in matters related to energy planning, which allows the management of all available resources to meet the needs of development.

Researchers at Stanford and universities in California in the United States are emphasizing the possibility of reducing the amount of pollutants that have were produced by power generation [19], improving conversion, decreasing costs and increasing generation efficiency and energy supply, objectives that can be achieved as generalized concepts of distributed generation and the use of renewable sources.

The problem has was identified in the lack of a model of sustainable energy planning, based on the use of renewable energy sources and the role a priori should play local community actors for its conception and development.

To achieve the application of a sustainable planning scheme, it has was materialized by levels and at different scales. At the regional level, the strategies and level of planning have was defined, focused on the inventory of renewable potentials and the satisfaction of demand as close as possible to the consumption sites, in such a way that losses due to transmission and distribution can be reduced.

This notion of planning supposes a consideration that goes further away from the electric service. Incorporating in an integrating way all the energy utilities that have was derived from the use of the renewable sources of energy as they can be. The pumping of water, its purification, the heating of fluids, the obtaining and use of renewable energy carriers through the recycling of waste and the management of the biological bottom for the production of biodiesel.

For the energetic planning, integral models to the problematic of each territory have was instrumented and not to transfer copied schemes with tendencies to generalize solutions, since it is known that the society develops in different levels and using diverse means with different characteristics.

The little experience the territories have in terms of the efficient use of renewable potentials and the possibilities of intervention in space. The limitation to any territorial claim to embark on the path of self-sufficiency through decentralized energy planning, where they can be incorporated in a coherent and integrated manner, the full range of energy services associated with renewable energy sources.

In these conditions and considering the technical possibilities currently possessed by the territories to achieve sustainable development and provide energy input from the local level. Was necessary to look for solutions related to community intervention, in matters related to energy planning and within it, the results of the evaluation of the renewable potentials, the possibilities of using the available space for the implementation of the systems, looking for a close link with the studies of environmental impacts and the reduction of natural disasters.

It was necessary to adopt a new methodological concept in the search for sustainable energy solutions. For which instruments and regulations has was created that favor investment in the appropriate spaces and in areas that meet the conditions, not only of the existence of renewable potential but also of a geographical nature, applying the requirements of territorial ordering, in function of determining the most suitable places to develop investments.

Territorial planning has was as an administrative technique to determine the occupation of the land for each type of energy because its size depends on the satisfaction of the demand. These are linked to larger cities, where there is always less space for investment and hence the need to use GIS, as a management tool and integrator in the process of analyzing suitable sites for investment, and can develop a competitive vision not only in the energy aspect but in the environmental, economic and social 
3.3 Some experiences in the study of renewable sources in the province of Manabí

There are experiences in works that apply models of territorial energy development to favor the adoption of a planning scheme adjusted to the interests of the territory and coherently addressed to the use of renewable sources in all its manifestations, where energy services are included as a form to reduce demand by increasing quality and efficiency.

The developed model includes environmental impact assessment, as it is an important instrument for the integration of the energy process, in the preparation and adoption of plans and programs that may have significant repercussions on the development of the process of penetration of renewable sources, guaranteeing the preparation for planning and the fulfillment of the objectives of sustainable development.

For the incorporation of renewable sources into the energy matrix, the application relative to the territorial programs for specific areas must be considered, where the conditions for the capture and use of these energies are assured. The zones will be called viable areas and will be studied for each type of renewable sources that are intended to be used.

The information must be combined with the evaluation of the existing renewable resources, proposing a planning model for the adequate intervention in the territory, respecting its environment and where the comparative advantages with respect to those of a conventional nature stand out.

The proposed methodology should constitute a reference tool for territorial studies, which affect planning and which includes the integration of energy plans into the territory, allowing for an integrated administrative action, for which the necessary collaboration between the competent companies is established in matters of energy, territorial planning and the research centers involved in the studies. This methodology will serve to prepare university students for the related courses for the use of energy, with a comprehensive and sustainable vision regarding the use and intervention of the territory.

The proposed model allows the application of energy policy, through direct participation of local community actors, with an integrated vision of the use of all available sources, aimed at incorporating renewable resources in each site, giving rise to a new paradigm of sustainability and progress, where in addition to environmental impacts, the risks of natural disasters are taken into account. This idea of planning means that each territory can adopt the most appropriate development model according to its own characteristics.

As a necessary element, the inclusion in the study of a group of protection criteria and compatibility parameters is included as part of the economic and energy feasibility analysis, which are aimed at strengthening the sectoral planning process in land use planning.

For the application of geographic information systems are taken as starting data, the work developed in the management of renewable energy sources, which justifies and demonstrates the ability of renewable energy to solve energy problems in isolated communities, At the same time they can be used in electricity generation systems in other levels and scales of planning, with the implementation of systems connected to the grid, representing a step forward in the way of energy independence and the reduction of environmental impacts.

It is based on an analysis carried out in the province of Manabí using a planning methodology and selecting the municipality of Portoviejo and the availability of the renewable solar and wind resource. In this territory, other studies could be implemented related to biomass potential, hydraulic, residuals of both agricultural production and industrial production, among others. The proposed model has its starting point in the analysis of the energy estimate, where the distributed generation and the existing renewable resource in the selected territory are studied, enabling the integrated comparison of all the existing energy potentialities. In Figure 3 the proposed model is shown.

The development of the model allows defining in detail the steps to be followed to make any type and investment, based on an integral study in territorial planning, such as conventional and renewable sources, as well as demand studies. articulation of safer and more sustainable investments.

Ramos, J. L. M., Pérez, A. V., Gámez, M. R., \& Zambrano, R. V. H. (2018). Renewable energy sources on the change of energy matrix in Manabi province. International Research Journal of Engineering, IT \& Scientific Research, 4(4), 17-29. https://doi.org/10.21744/irjeis.v4n4.255 


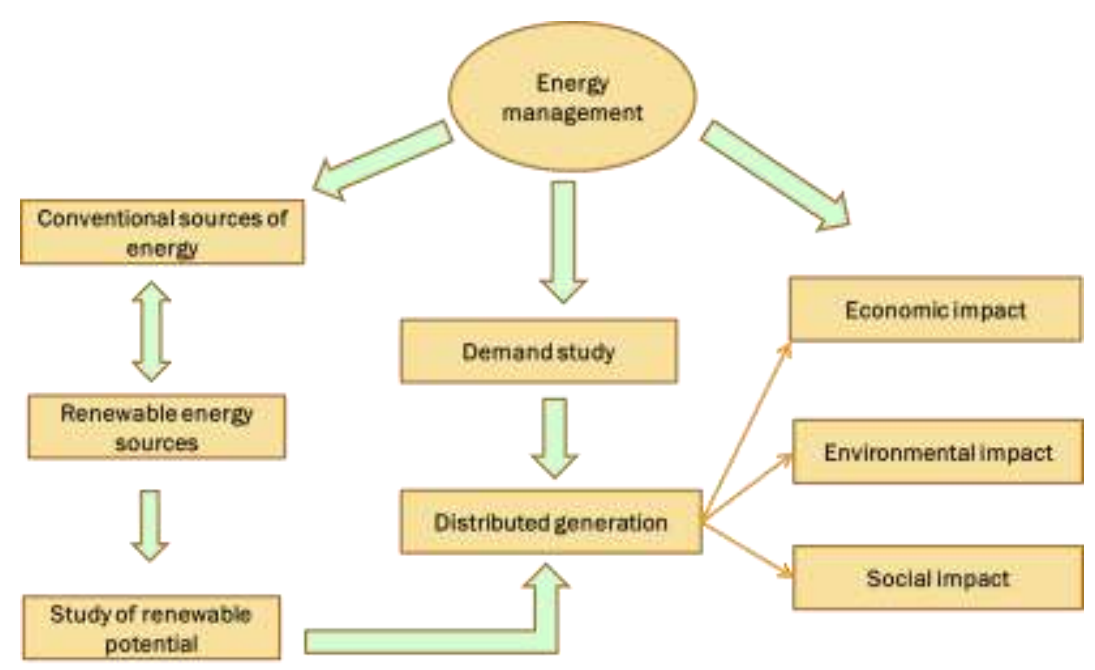

Figure 3. Model for energy management

For the studies of the potentials, the data published by NASA was taken as a reference on its website (NASA-seemonthly-average-wind-data-at-one-degree-resolution-of-the-world) [20][21]. Figure 4 shows the solar potential of the province of Manabí and especially the municipality of Portoviejo.

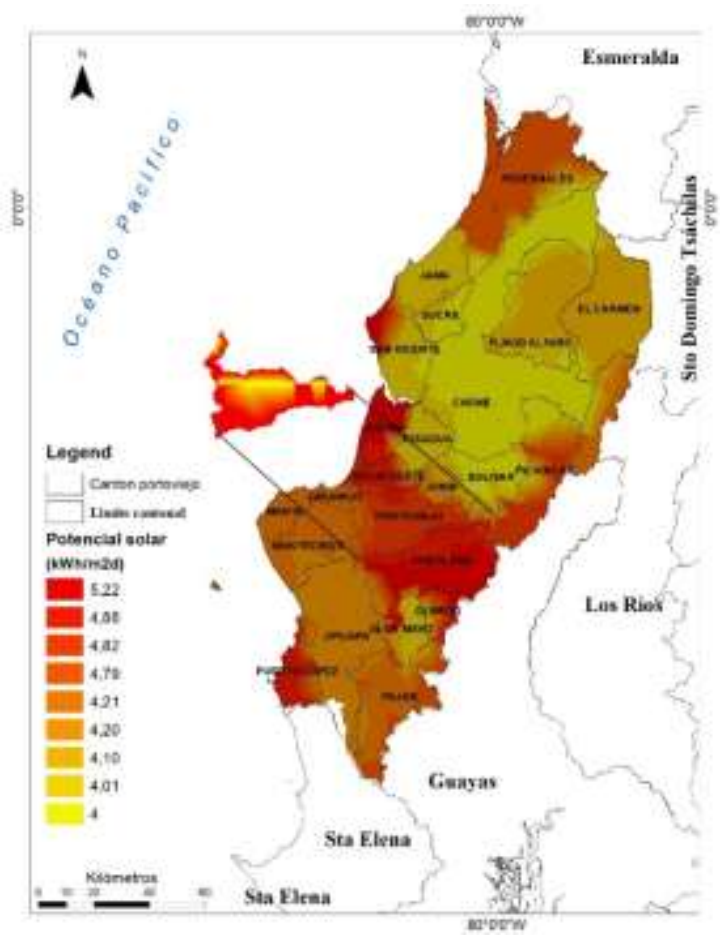

It can be observed in figure 4 that the solar radiation of the municipality of Portoviejo is among those with the greatest potential in the province. Figure 5 shows the information referring to the wind speed of the province and especially the municipality of Portoviejo [18][22]. 


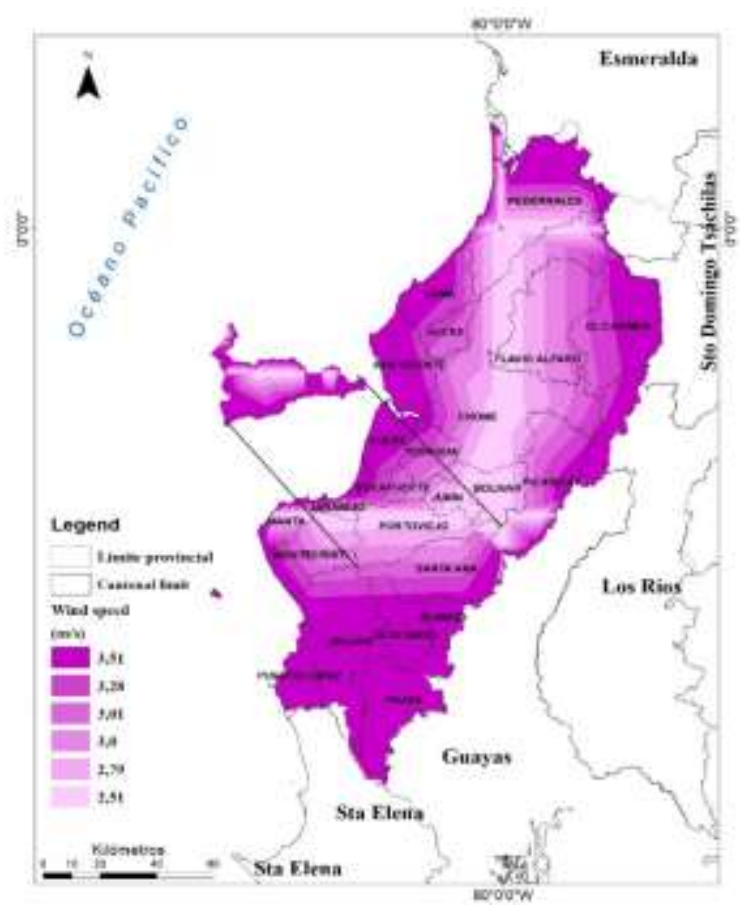

Figure 5. Wind speed in the province of Manabí and Portoviejo

It is observed that the wind behavior in the province is not very high and is found mainly in the north-west area. The municipality of Portoviejo only has a small area to the north, where the speed is 2.80 to $2.95 \mathrm{~m} / \mathrm{s}$.

Another result that can be shown is related to the hydraulic potential of the province, although it is still studied in detail. Figure 6 shows the map of the main rivers of the province and where studies of the potential are currently carried out by university students who perform a survey of their real conditions to generate energy in the distributed generation model.

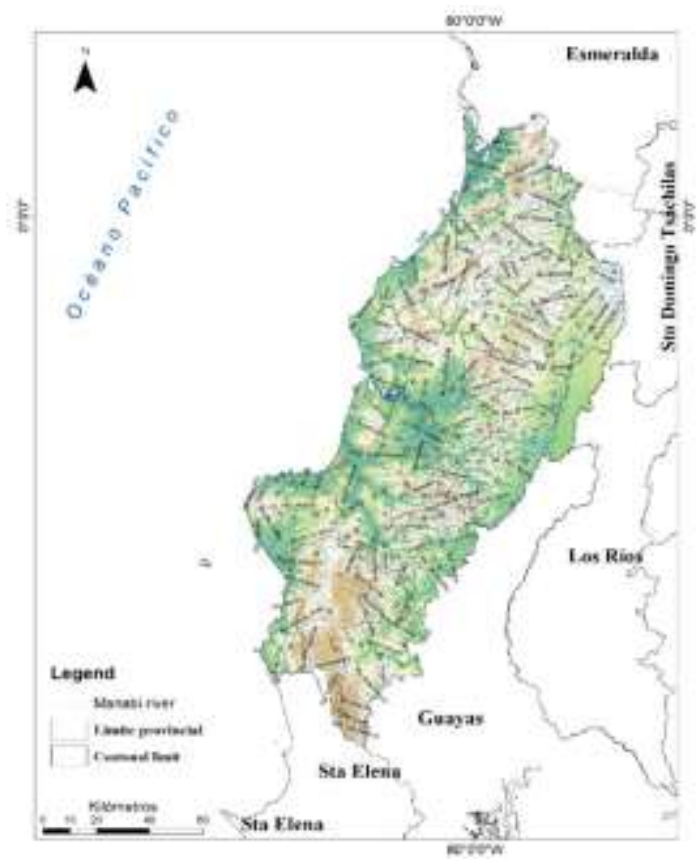

Figure 6. Main rivers of the province of Manabí

Ramos, J. L. M., Pérez, A. V., Gámez, M. R., \& Zambrano, R. V. H. (2018). Renewable energy sources on the change of energy matrix in Manabí province. International Research Journal of Engineering, IT \& Scientific Research, 4(4), 17-29. https://doi.org/10.21744/irjeis.v4n4.255 
Another result is related to the study of the plantations of Jatrofha curcas that exist in the province of Manabí, based on the production of biodiesel. Figure 7 shows the map where the cultivation areas of the Jatrofha curcas are specified [19][23].

The general results achieved so far show that the most populated areas are located in the southern part of the Manabi territory, and may suggest that the best option to make investments corresponds to solar energy through the introduction of photovoltaic systems connected to the network, which helps decrease the demand during the daytime. The possibility of having studies of biomass, tidal and hydraulic resources, among others, will make it possible to compare alternatives considering the use of resources in an integrated manner.

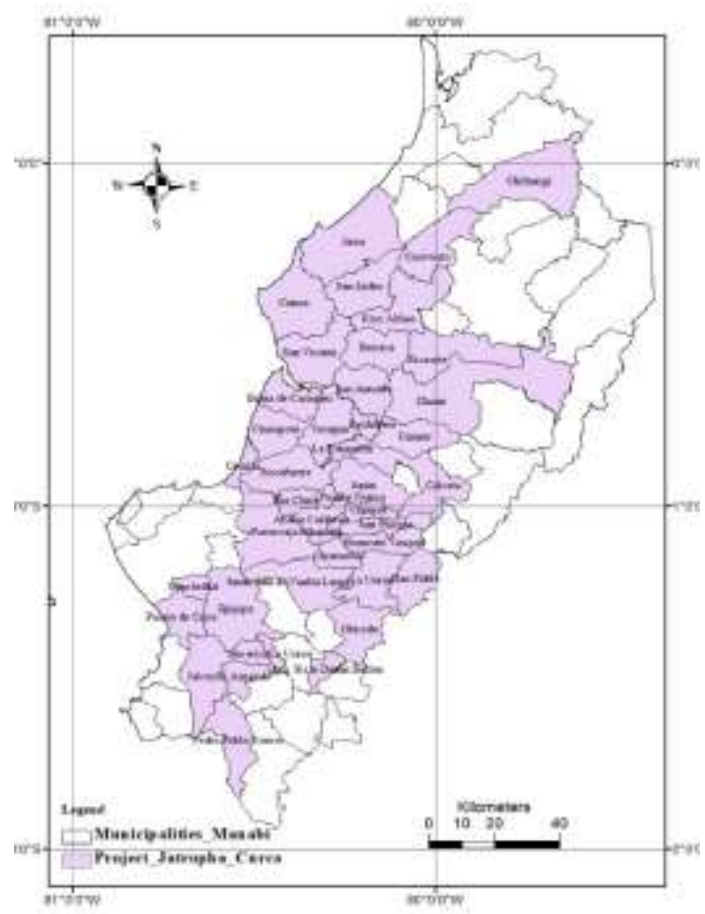

Figure 7. Cultivation areas of Jatropha curcas in the province of Manabí

\subsection{Impacts derived from the proposal}

Among the impacts derived from the proposal are the economic, environmental and social impacts

a) Economic impact

The main economic impact is that at present the base generation in the province of Manabí is of thermal origin, with an approximate cost between 0.43 and $0.50 \mathrm{kWh}$ served to consumers. However, there is a flat rate for the collection of electric service throughout the country, with a value between 0.10 and 0.12 cents per $\mathrm{kWh}$ consumed in the residential sector. This means that for each kWh of electricity generated with renewable energy sources that are supplied to the service, you can save between 0.33 and 0.38 cents per dollar since renewable generation is done with a virtual cost equal to zero for fuel concepts., because the Sun, water and wind are available in the territory and can be used without the need for commercialization.

In addition to the above, it can be said that with the adequate use of renewable sources the following results are achieved:

Reduction of energy losses and thus reduce the cost of $\mathrm{kWh}$ served, contributing to increasing the economic efficiency of electricity service and a greater availability of economic resources of the state; In the installations that are carried out in institutions, organizations and in the residential sector, it is possible to reduce the amount of the electric service bill; The use of renewable sources in the distributed generation mode is conducive to saving investments in transformers, power lines, poles and other technical components, which represents a saving of economic resources for investments. 
b) Environmental impact

The main negative environmental effects associated with the introduction of renewable technology will be related to the occupation of space and the visual intrusion into the landscape caused by the introduction of renewable equipment. But the possibility of using a part of the roof surface of the building to locate the photovoltaic technology or the use of idle or little-used land significantly reduces the effects of the occupation of the area. The visual intrusion may be minimal when the introduction of renewable technologies is properly combined with novel architectural solutions.

Among the benefits and environmental benefits of renewable technology, the following can be pointed out:

to. In most cases little or no noise is generated in its operation; Some technologies such as photovoltaics have no moving parts; Some of the technologies associated with renewable sources, such as solar and wind, do not need to be supplied with fuels, since they are self-supplying the Sun and the wind; Gas emissions are not considered harmful and in some cases do not emit polluting gases in their exploitation stage; and. When installed on the roof of the buildings, it can reduce the transfer of heat to the interior, benefiting the air conditioning of the premises and with it the energy saving by the climate equipment.

These characteristics distinguish renewable sources of energy invaluable reductive technological solutions of environmental impacts.

c) Social impact

The social impact is an element that can hardly be achieved through the traditional ways of implementing energy. Renewable technologies allow, like no other source, the relocation of the energy resource very close to the social actors that appear as the main customers of the electricity service and this can be an influential element for the adoption of new positions of consumption and responsibility depending on the preservation of resources and adoption of patterns of energy use and expenditure appropriate to the real needs of work and people.

The massive introduction of technologies that favor the use of renewable sources in the province of Manabí, favoring a significant change in the role of society in the face of the energy profile, from being a simple consumer, to a social figure capable of generating a part of the electricity it consumes through the use of its own resource, clean and inexhaustible as renewable energy sources can be.

Depending on the characteristics of the current energy scenario in the province of Manabí, the sustainability of development can be achieved as long as the independence of non-renewable resources for energy generation is achieved, only in this way can it be met the social commitment of manabitas to achieve sustainable development.

\section{Conclusion}

The development of the work made it possible to demonstrate the social feasibility of carrying out the diversification of the energy matrix, of the province of Manabí. Through the gradual and progressive use of renewable energy sources, which will allow transforming energy generation into a sustainable function, achieving the appropriate use of territorial resources with the use of technologies within the reach of the country's possibilities.

A working model is presented that allows carrying out the study for the use of renewable sources and their incorporation into the energy matrix, contributing to the structuring of a technical scheme of generation, distribution and sustainable consumption of energy at the level of the society.

The results obtained allow the development of strategies that make it possible to carry out integrated analyzes according to the conditions of each territory, taking into account the demand and the incorporation of issues related to economic, environmental, socio-cultural and natural disaster impacts.

\section{Conflict of interest statement and funding sources}

The authors declared that they have no competing interest. The study was financed by the authors themselves.

\section{Statement of authorship}

The authors have a responsibility for the conception and design of the study. The authors have approved the final article.

\section{Acknowledgments}

The authors thank the editor of IRJEIS journal for their valuable time and advice.

Ramos, J. L. M., Pérez, A. V., Gámez, M. R., \& Zambrano, R. V. H. (2018). Renewable energy sources on the change of energy matrix in Manabi province. International Research Journal of Engineering, IT \& Scientific Research, 4(4), 17-29. https://doi.org/10.21744/irjeis.v4n4.255 


\section{References}

1. Jover, J. N. (2002). Ética, Ciencia y Tecnología: Sobre la función social de la tecnología. Llull: Revista de la Sociedad Española de Historia de las Ciencias y de las Técnicas, 25(53), 459-484.

2. Rasero, C. M. (2011). Energía solar fotovoltaica. Energía solar fotovoltaica, situación actual.

3. Barrere, R., Castro Martínez, E., Fernández de Lucio, I., Gordon, A., Jacovkis, P., Polino, C., ... \& Silenzi, M. (2012). Ciencia, tecnología e innovación para el desarrollo y la cohesión social. Programa iberoamericano en la década de los bicentenarios.

4. Shirley, R., \& Kammen, D. (2015). Kampung Capacity: Assessing the Potential for Distributed Energy Resources to Satisfy Local Demand in East Malaysia. University of California, Berkeley.

5. Prieto Ramírez, D., Aguirre del Busto, R., \& Colectivo de autores, editores. (2000). La salud como valor social. Lecturas de filosofía, salud y sociedad.

6. Constituyente, E. A. (2008). Constitución de la República del Ecuador.

7. Barnes, D. F., \& Floor, W. M. (1996). Rural energy in developing countries: a challenge for economic development1. Annual review of energy and the environment, 21.

8. Turrini, E., MONTESINOS, A., \& CALZADILlA, A. (2010). Solarización territorial. Vía para el logro del desarrollo sostenible. Editorial Cubasolar, La Habana.

9. Francés, G. E., Marín-Quemada, J. M., \& González, E. S. M. (2013). RES and risk: Renewable energy's contribution to energy security. A portfolio-based approach. Renewable and Sustainable Energy Reviews, 26, 549-559.

10. Dominguez, J., \& Marcos, M. J. (2000). Análisis de la producción potencial de energía con biomasa en la región de Andalucía (España) utilizando sistemas de información geográfica. Cybergeo: European Journal of Geography.

11. Amador Guerra, J. (2000). Análisis de los parámetros técnicos en la aplicación de los sistemas de información geográfica a la integración regional de las energías renovables en la producción descentralizada de electricidad (Doctoral dissertation, Industriales).

12. Bosque Sendra, J. (1992). Sistemas de información geográfica (No. 005.75/B74s).

13. GÁMEZ, M. R. (2011). La ordenación y la planificación de las fuentes renovables de energía en la Isla de Cuba desde una perspectiva territorial. Estudio de caso en el municipio de Guamá a partir de un Geoportal. Memoria presentada para obtener el grado de Doctora en Ciencias.

14. Schmitt, A. (1997, July). EDFs approach for the use of renewable energies for decentralised rural electrification. In 14th European Photovoltaic Solar Energy Conference (Vol. 1).

15. Jacobson, M. Z., \& Delucchi, M. A. (2011). Providing all global energy with wind, water, and solar power, Part I: Technologies, energy resources, quantities and areas of infrastructure, and materials. Energy policy, 39(3), 11541169.

16. Martins, F. R., Pereira, E. B., \& Abreu, S. L. (2007). Satellite-derived solar resource maps for Brazil under SWERA project. Solar Energy, 81(4), 517-528.

17. Martins, F. R., Rüther, R., Pereira, E. B., \& Abreu, S. L. (2008). Solar energy scenarios in Brazil. Part two: Photovoltaics applications. Energy Policy, 36(8), 2865-2877.

18. Pérez, G. L. R., Ávila, A. A. H., Gámez, M. R., \& Pérez, A. V. Seguridad, ambiente y fuentes renovables de energía.

19. Muentes, S. A. G., Ávila, M. G. G., Vázquez, B. L. L., \& del Campo Laffita, A. E. S. (2017). The Production of Biodiesel from Jatropha Curca and Its Social Impact. International Research Journal of Engineering, IT and Scientific Research (IRJEIS), 3(6), 85-94.

20.Cedeño, M. L. D., Arteaga, M. G. D., Pérez, A. V., \& Arteaga, M. L. D. (2017). Regulatory Framework for Renewable Energy Sources in Ecuador Case Study Province of Manabí. International Journal of Social Sciences and Humanities (IJSSH), 1(2), 29-42.

21.Gámez, M. R., Pérez, A. V., Será, A. S., \& Ronquillo, Z. M. (2017). Renewable Energy Sources and Local Development. International Journal of Social Sciences and Humanities (IJSSH), 1(2), 10-19.

22.González, A. E. D., Arauz, W. M. S., Gámez, M. R., \& Alava, L. A. C. (2017). Photovoltaic Energy to Face an Earthquake. International Journal of Physical Sciences and Engineering (IJPSE), 1(3), 19-30. 


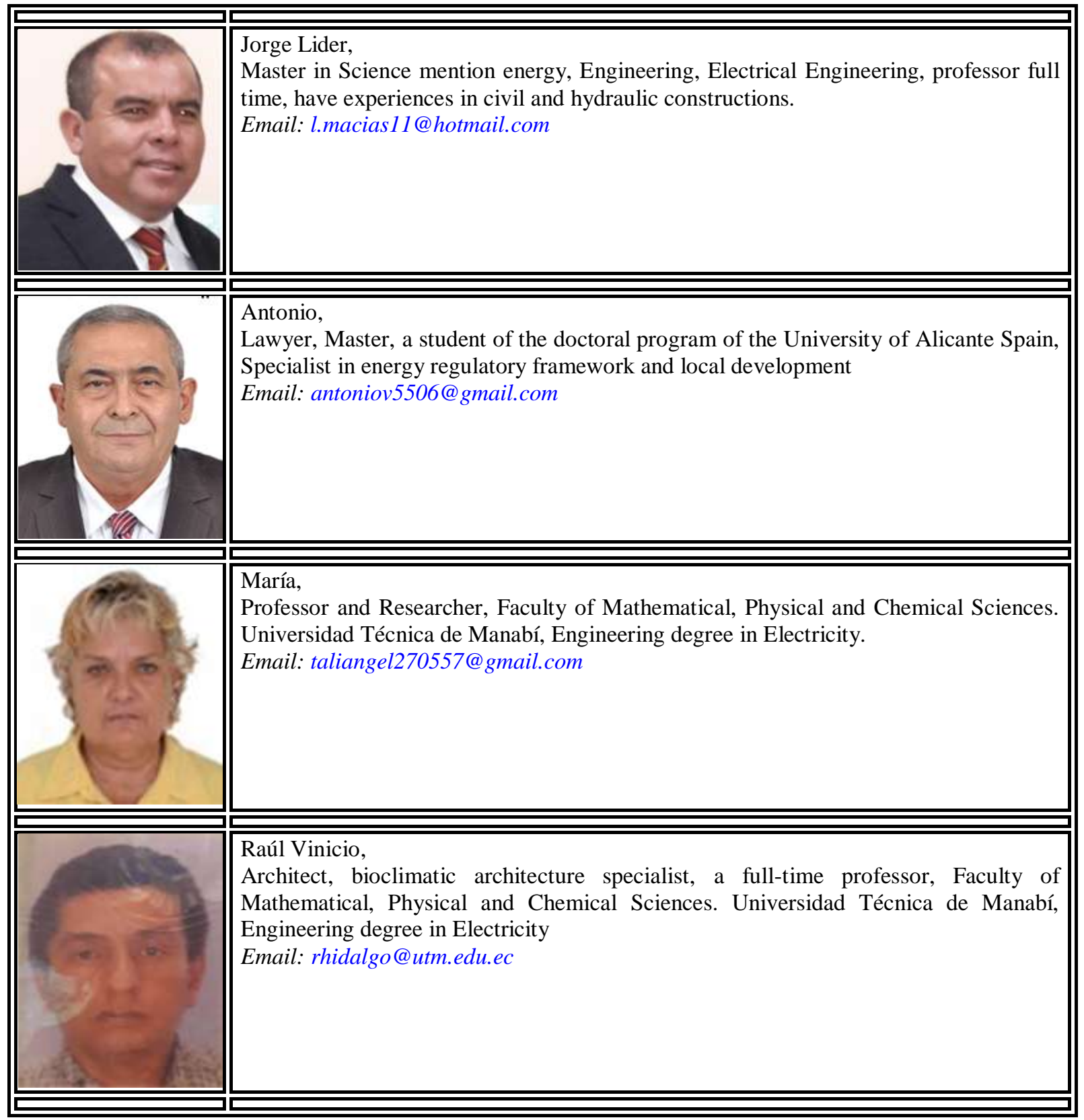

Ramos, J. L. M., Pérez, A. V., Gámez, M. R., \& Zambrano, R. V. H. (2018). Renewable energy sources on the change of energy matrix in Manabi province. International Research Journal of Engineering, IT \& Scientific Research, 4(4), 17-29. https://doi.org/10.21744/irjeis.v4n4.255 